\title{
PENGARUH ARUS KAS OPERASI DAN RETURN ON ASSET (ROA) TERHADAP HARGA SAHAM STUDI PADA PERUSAHAAN PERBANKAN YANG TERDAFTAR DI BURSA EFEK INDONESIA
}

\author{
Fita Enjelina Rawung ${ }^{1}$, Stanly W. Alexander ${ }^{2}$, Meily Y.B. Kalalo ${ }^{3}$ \\ ${ }^{1}$ Jurusan Akuntansi, Fakultas Ekonomi dan Bisnis, Universitas Sam Ratulangi, Alamat, Manado, 95115, \\ Indonesia \\ ${ }^{2}$ Jurusan Akuntansi, Fakultas Ekonomi dan Bisnis, Universitas Sam Ratulangi, Alamat, Manado, 95115, \\ Indonesia \\ E-mail : enjelinarawung@yahoo.com
}

\begin{abstract}
Indonesian is a country that embraces the financial system on the bank. The purpose of banking is to support the implementation of national development to improve equity, economic growth, and national stability towards the improvement of people's welfare. The purpose of this study is to determine the effect of operating cash flow and returnon asset (ROA) to stock price studies on banking companies listed on the stock exchange Indonesia. Population of 42 bank and samples used by 30 banks. In the examinations examined in this study, only the results obtained flow of operations and return on asset (ROA) that positive number and sample data overall stock price are all used because there is nonegative number. Research method used in this research is quantitative research with multiple linear regression analysis technique by using SPSS 20 program. The results showed that operating cash flow has no significant effect on stock price and return on asset (ROA) significant effect on stock price. As a recommendation, investors ahould be able to pay attention and analyze operating cash flow and return on asset (ROA) and stock price movements to gain profit.
\end{abstract}

Keywords : Operating Cash Flow, Retur On Asset (ROA) and Stock Price.

\section{PENDAHULUAN}

Di era globalisasi saat ini, para pelaku bisnis saling berlomba-lomba dalam mengoptimalkan nilai perusahaan serta meningkatkan kinerja ekonomi agar dapat terus bertahan dalam persaingan yang ada. Indonesia sebagai negara berkembang pun ikut membenahi sektor ekonomi, keuangan serta pasar modalnya. Menurut Otoritas Jasa Keuangan (OJK), Indonesia disebut sebagai Investemen Great yaitu Lahan subur yang sangat potensial bagi para investor yang ingin menginvestasikan modal yang dimiliki. Salah satu tempat untuk berinvestasi adalah pasar modal. Menurut (Hutami, 2012) pasar modal adalah pertemuan antara pihak yang memiliki kelebihan dana dengan pihak yang membutuhkan dana dengan cara memperjual belikan sekuritas. Sedangkan pasar modal menurut UndangUndang Pasar Modal No. 8 tahun 1995 yaitu, pasar modal adalah suatu kegiatan yang bersangkutan dengan penawaran umum dan perdagangan efek, perusahaan publik yang berkaitan dengan efek yang diterbitkan, serta lembaga dan profesi yang berkaitan dengan efek. Menurut Kasmir (2012: 184), menyatakan pasar modal secara umum adalah suatu tempat bertemunya para penjual dan pembeli untuk melakukan transaksi dalam rangka memperoleh modal.

Indonesia merupakan negara yang menganut sistem keuangan berdasarkan bank. Menurut Undang-Undang RI No 10 Tahun 1998 tanggal 10 November 1998 tentang Perbankan, yang dimaksud dengan BANK adalah "Badan usaha yang menghimpun dana dari masyarakat dalam bentuk simpanan dan menyalurkannya kepada masyarakat dalam bentuk kredit dan atau bentuk-bentuk lainnya dalam rangka meningkatkan taraf hidup rakyat banyak". Dalam pasal 4 Undang-Undang Perbankan tahun 1992, tujuan perbankan adalah 
menunjang pelaksanaan pembangunan nasional untuk meningkatkan pemerataan, pertumbuhan ekonomi, dan stabilitas nasional menuju peningkatan kesejahteraan masyarakat. Pasar modal (capital market) merupakan pasar untuk berbagai instrumen keuangan jangka panjang yang bisa diperjualbelikan, baik surat utang (obligasi), ekuiti (saham), reksa dana, instrumen derivatif maupun instrumen lainnya. Pasar modal merupakan sarana pendanaan bagi perusahaan maupun institusi lain misalnya pemerintah, dan sebagai sarana bagi kegiatan berinvestasi. Dengan demikian, pasar modal memfasilitasi berbagai sarana dan prasarana kegiatan jual beli dan kegiatan terkait lainnya. Salah satu tempat untuk berinvestasi adalah pasar modal (Watung, 2016).

Saham merupakan salah satu istrumen yang di perdagangkan di Bursa Efek Indonesia. Dalam suatu investasi saham, harga dapat dianggap penting karena dari harga saham tersebut investor dapat menyesuaikan dengan dana yang dimilikinya serta memberikan ukuran yang obyektif tentang nilai investasi pada perusahaan. Peningkatan dan penurunan sangat penting bagi perusahaan dan investor. Bagi perusahaan, harga saham yang tinggi akan meningkatkan nilai perusahaan, sehingga banyak investor yang akan menanamkan modalnya pada perusahaan tersebut, sedangkan bagi investor dapat meningkatkan return yang akan di perolehnya dari saham yang dimilikinya. Sebaiknya, jika harga saham turun, maka akan menurunkan nilai perusahaan dimata investor, sedangkan bagi investor dapat menimbulkan kerugian terhadap modal yang ditanamkan di perusahaan tersebut (Sonia, 2013). Harga saham merupakan nilai sekarang (present value) dari penghasilan-penghasilan yang akan diterima oleh pemodal di masa yang akan datang (Husnan, 2009: 151).

Laporan arus kas baru diwajibkan pelaporannya sejak tahun 1987, melalui Statement of Financial Accounting Standards (SFAS), yang mengatur bahwa laporan keuangan yang semula hanya terdiri dari neraca, laporan laba rugi, dan laporan perubahan modal, harus ditambahkan dengan laporan arus kas. Sedangkan, di Indonesia sendiri perusahaanperusahaan diwajibkan untuk melaporkan laporan keuangan arus kas sejak tahun 1994, melalui Pernyataan Standar Akuntansi Keuangan (PSAK) No. 2 yang menyatakan bahwa perusahaan harus menyusun laporan arus kas dan menyajikan laporan tersebut sebagai bagian yang tak terpisahkan dari laporan keuangan. Oleh karena itu, Ikatan Akuntan Indonesia (IAI) mengubah penyajian laporan perubahan posisi keuangan yang semula berupa laporan arus dana menjadi laporan arus kas yang diklasifikasikan berdasarkan aktivitas operasi, investasi, dan pendanaan selama satu periode akuntansi. Laporan arus kas sendiri diklasifikasikan ke dalam tiga bentuk aktivitas, yaitu aktivitas operasi, investasi, dan pendanaan. Menurut Raja Adri (2012: 47), klasifikasi arus kas menurut aktivitasnya memberikan informasi yang memungkinkan para pengguna laporan untuk menilai pengaruh aktivitas tersebut terhadap posisi keuangan perusahaan serta terhadap jumlah kas dan setara penyajian kas. Informasi tersebut juga dapat digunakan untuk mengevaluasi hubungan diantara ketiga aktivitas tersebut. Penelitian yang dilakukan oleh Kurniawan (2013) menyatakan bahwa arus kas operasi per lembar saham merupakan prediktor yang lebih terhadap dividen pada perusahaan besar. Dividen yang dibagikan pada investor merupakan hasil perolehan laba yang dihasilkan perusahaan, semakin besar laba yang diperoleh maka semakin besar pula dividen yang akan diterima oleh investor. Sehinggga arus kas operasi memiliki hubungan dan berpengaruh terhadap laba dimasa yang akan datang.

Return On Asset (ROA) mampu memberikan informasi bagi investor dan kreditor karena ROA menunjukkan kinerja manajemen dalam menggunakan aktiva perusahaan untuk menghasilkan laba berdasarkan tingkat aktiva yang tertentu. ROA dapat dihitung dengan membagi laba bersih dengan total aktiva. Jika ROA suatu perusahaan tinggi maka dapat dikatakan bahwa perusahaan beroperasi secara efektif dan ini akan meningkatkan daya tarik investor. Meningkatnya daya tarik investor akan berdampak pula pada kenaikan harga saham dan meningkatkan return saham perusahaan (Anjani 2016). 
Berdasarkan dari uraian penjelasan diatas, maka peneliti tertarik melakukan penelitian dengan menetapkan judul penelitian yaitu "Pengaruh Arus Kas Operasi dan Return On Asset (ROA) Terhadap Harga Saham Studi Pada Perusahaan Perbankan Yang Terdaftar Di Bursa Efek Indonesia".

\section{TINJAUAN PUSTAKA \\ 2.1 Kajian Teori \\ 2.1.1 Konsep Akuntansi}

Akuntansi adalah proses pencatatan, pengklasifikasian dan pengelompokkan semua transaksi yang terjadi dalam bentuk laporan keuangan untuk memberikan informasi kepada perusahaaan dan kepada pihak yang membutuhkan. Secara umum akuntansi (accounting) dapat diartikan sebagai sistem informasi yang menyediakan laporan untuk para pemangku kepentingan mengenai aktivitas ekonomi dan kondisi perusahaan (Reeve. Et, al. 2013:9).

\subsubsection{Akuntansi Keuangan}

Akuntansi keuangan merupakan bidang akuntansi yang menyediakan informasi akuntansi secara umum bagi para pemakai atau pengambil keputusan yang ada diluar organisasi. Akuntansi Keuangan (financial accounting) sangat terkait dengan pencatatan dan pelaporan data dari aktivitas ekonomi suatu perusahaan. Selain laporan ini berguna bagi manajer, laporan tersebut juga menjadi laporan utama bagi pemilik usaha, kreditor, badan pemerintah, dan masyarakat (Reeve. et, al. 2013:10).

\subsubsection{Laporan Keuangan}

Dalam Pernyataan Standar Akuntansi Keuangan No.1 (IAI,2012), tujuan laporan keuangan adalah memberikan informasi tentang posisi keuangan, kinerja, dan arus kas perusahaan yang bermanfaat bagi pengguna laporan keuangan dalam rangka membuat keputusan-keputusan ekonomi serta menunjukkan pertanggung jawaban manajemen atas penggunaan sumber daya yang dipercayakan kepada mereka. Menurut Hery (2015:3) Laporan keuangan (financial statements) merupakan produk akhir dari serangkaian proses pencatatan dan pengikhtisaran data transaksi bisnis. Menurut Kasmir (2015:8), laporan keuangan menggambarkan pos-pos keuangan perusahaan yang diperoleh dalam suatu periode. Dalam praktiknya dikenal beberapa macam laporan keuangan:

1. Neraca.

2. Laporan laba-rugi.

3. Laporan perubahan modal.

4. Laporan catatan atas laporan keuangan.

5. Laporan arus kas.

\subsection{Arus Kas}

Arus kas merupakan salah satu dari beberapa bentuk laporan keuangan sebuah perusahaan. Laporan arus kas adalah ringkasan aliran kas untuk suatu periode tertentu (1 tahun). Laporan ini kadang disebut sebagai "laporan sumber dan penggunaan dana" yang menunjukkan aliran operasi perusahaan, investasi, dan aliran kas pendanaan serta menunjukkan perubahan kas dan surat berharga selama periode tersebut. Penyajian laporan arus kas dibagi menjadi 3 bagian, yaitu:

1. Arus kas dari aktivitas operasi

Menurut Raja Adri (2012: 48), jumlah arus kas yang berasal dari aktivitas operasi merupakan indikator yang menentukan apakah dari operasinya perusahaan dapat menghasilkan arus kas yang cukup untuk melunasi pinjaman, memelihara kemampuan operasi perusahaan, membayar deviden, dan melakukan investasi baru tanpa mengandalkan pada sumber pendanaan dari luar.

2. Arus kas dari aktivitas investasi 
Arus kas dari aktivitas investasi berhubungan dengan pembelian dan penjualan aktiva tetap maupun investasi lain, dimana pembelian mengakibatkan arus kas keluar dan transaksi penjualan menghasilkan arus kas masuk.

3. Arus kas dari aktivitas pendanaan

Arus kas dari aktivitas pendanaan adalah arus kas yang dihasilkan dari pinjaman dan ekuitas.

\subsection{Return On Asset (ROA)}

Return on asset (ROA) yang sering disebut juga return on investment adalah pengukuran kemampuan perusahaan secara keseluruhan di dalam menghasilkan keuntungan dengan jumlah keseluruhan aktiva yang tersedia di dalam perusahaan. Return on asset (ROA) dipengaruhi dua faktor, yaitu laba bersih dan total aktiva. Dimana secara teoritis untuk meningkatkan ROA dapat dilakukan dengan meningkatkan laba bersih setelah pajak dan mengurangi total aktiva yang diinvestasikan perusahaan (Kasmir 2012: 197).

\subsection{Harga Saham}

Wauran dan Tumbuan (2014), saham atau stock adalah surat tanda bukti atau tanda kepemilikan terhadap suatu perusahaan suatu perseroan terbatas. Dalam transaksi jual beli di bursa efek, saham atau sering disebut share merupakan instrumen yang paling dominan diperdagangkan. Saham dapat diterbitkan dengan cara atas nama atau atas unjuk. Selanjutnya saham dibedakan antara saham biasa (common stock) dan saham preferen (perferrend stock).

\subsection{Kerangka Pemikiran Teoritis}

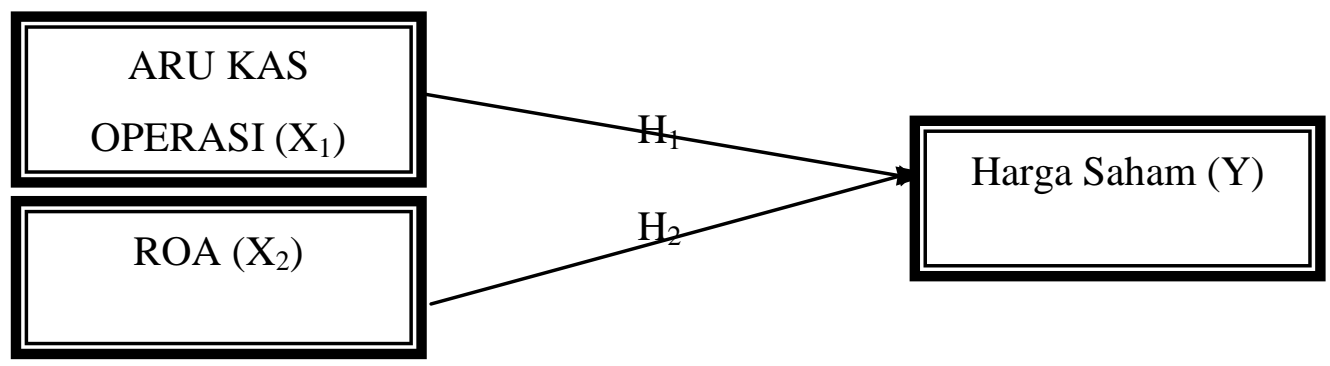

Gambar 1. Kerangka Pemikiran Teoritis

Sumber: Data Penelitian yang telah diolah, 2017

\subsection{Hipotesis}

Berdasarkan kajian teori dan kerangka pemikiran diatas maka hipotesis yang diajukan dalam penelitia ini adalah:

1. Arus Kas Operasi berpengaruh positif terhadap Harga Saham.

2. Return On Asset (ROA) berpengaruh positif terhadap Harga Saham.

\subsection{Penelitian Terdahulu}

Watung (2016) dalam penelitian Pengaruh Return On Asset (ROA), Net Profit Margin (NPM), dan Earning Per Share (EPS) terhadap harga saham pada Perusahaan Perbankan Di Bursa Efek Indonesia Periode 2011-2015. Hasil penelitian menunjukkan bahwa ROA, NPM dan EPS berpengaruh signifikan terhadap harga saham, secara simultan dan parsial. Perbedaannya Penelitian ini menambakan NPM dan EPS.

Sulia (2012) dalam penelitian Pengaruh Laba Akuntansi, Arus Kas, Dan Debt To Equity Terhadap Harga Saham Perusahaan LQ-45 Yang terdaftar di Bursa Efek Indonesia. Berdasarkan hasil pengujian, diperoleh bahwa secara uji simultan laba akuntansi (LAK), arus kas operasi (AKO), arus kas investasi (AKI), arus kas pendanaan (AKP) dan debt to equity ratio (DER) berpengaruh signifikan terhadap harga saham. Perbedaannya penelitian ini menambahkan laba akuntansi, arus kas investasi, arus kas pendanaan dan debt to equity ratio. 
Kadarusman (2014) dalam penelitian Pengaruh Laba Akuntansi, Komponen Arus Kas, Ukuran Perusahaan Terhadap Harga Saham Pada Perusahaan Kelompok LQ 45 Yang Listing di Bursa Efek Indonesia. Hasil menunjukkan, laba akuntansi, arus kas total, arus kas operasi, arus kas investasi, arus kas pendanaan, ukuran perusahaan tidak berpengaruh secara signifikan terhadap harga saham. Perbedaannya penelitian ini menambakan Laba akuntansi, arus kas total, arus kas investasi, arus kas pendanaan, ukuran perusahaan.

\section{METODE PENELITIAN}

\subsection{Jenis Penelitian}

Jenis penelitian yang digunakan dalam penelitian ini adalah penelitian kuantitatif berupa angka atau bilangan yang absolut dapat dikumpulkan dan dibaca relative lebih mudah, yaitu menggambarkan data yang diperoleh dan menganalisis data yang ada secara kuantitatif (statistik).

\subsection{Tempat dan Waktu Penelitian}

Penelitian dilakukan pada Bursa Efek Indonesia yaitu Perusahaan Perbankan yang terdaftar di Bursa Efek Indonesia, yang beralamat di Galeri Investasi Bursa Efek Indonesia, Universitas Sam Ratulangi. Periode pengamatan untuk hasil penelitian adalah selama bulan 3 (tiga) bulan.

\subsection{Prosedur Penelitian}

Prosedur penelitian dalam penelitian ini adalah pengumpulan data penelitian sesuai jumlah populasi dan sampel pada perusahaan perbankan yang terdaftar di Bursa Efek Indonesia.

\subsection{Populasi dan Sampel}

Populasi yang digunakan dalam penelitian ini adalah perusahaan perbankan yang terdaftar di Bursa Efek Indonesia dari tahun 2013 sampai dengan 2016 sebanyak 30 perusahaan. Sampel yang digunakan dengan mengunakan teknik Purposive Samplin, yaitu teknik penentuan sampel dengan pertimbangan tertentu.

\subsection{Metode Pengumpulan Data}

\subsubsection{Jenis Data}

Jenis data yang digunakan dalam penelitian ini adalah data kuantitatif berupa data laporan keuangan dan catatan atas laporan keuangan pada perusahaan perbankan yang terdaftar di Bursa Efek Indonesia.

\subsubsection{Sumber Data}

Sumber data yang digunakan dalam penelitian ini adalah data sekunder. Keseluruhan data diperoleh dari website Bursa Efek Indonesia yaitu www.idx.co.id.

\subsection{Metode Analisis}

\subsubsection{Metode Regresi Linear Berganda}

Metode analisis yang digunakan dalam penelitian ini yaitu analisis regresi berganda dengan program SPSS 20. Menurut Ghozali (2011: 13), regresi linear berganda yaitu menguji pengaruh dua atau lebih variabel independen terhadap satu variabel dependen.

\subsubsection{Pengujian Asumsi Klasik}

\section{Uji Normalitas}

Uji normalitas bertujuan untuk menguji apakah dalam model regresi, variabel bebas dan variabel terikat keduanya memiliki distribusi normal atau tidak. Normalitas juga dapat dideteksi dengan menggunakan uji Kolmogorov-Smirnov (Ghozali, 2011: 160).

2. Uji Multikoloniearitas

Uji multikolonieritas dilakukan untuk menguji apakah model regresi memiliki korelasi antar variabel bebas. Cara untuk mendeteksi adanya multikoloniearitas adalah dengan melihat nilai tolerance dan nilai Variance Inflation Factor (VIF).

3. Uji Autokorelasi 
Uji autokorelasi bertujuan untuk menguji apakah dalam model regresi terdapat korelasi antara kesalahan pengganggu pada periode sebelumnya (t-1). Cara untuk mendeteksi adanya autokorelasi adalah dengan menggunakan uji Lagrange Multiplier (LM test) yang akan menghasilkan statistik Breusch-Godfrey. Uji LM digunakan untuk sampel besar di atas 100 observasi dan lebih tepat digunakan dibandingkan uji Durbin-Watson (Ghozali, 2011: $113)$.

4. Uji Heteroskedastisitas

Uji heteroskedastisitas bertujuan untuk menguji apakah dalam model regresi terjadi ketidaksamaan variance dari residual satu pengamatan ke pengamatan lain. Cara untuk mendeteksi adanya heteroskedastisitas adalah dengan melihat grafik scatterplot.

\subsubsection{Pengujian Hipotesis}

\subsubsection{Uji F}

Uji statistik F pada dasarnya menunjukkan apakah semua variabel independen atau bebas yang dimasukkan dalam model mempunyai pengaruh secara simultan terhadap variabel dependen atau terikat.

\subsubsection{Uji T}

Uji statistik t pada dasarnya menunjukkan seberapa jauh pengaruh satu variabel penjelas atau independen secara individual dalam menerangkan variasi variabel dependen.

\subsubsection{Analisis Koefisien Determinasi $\left(\mathbf{R}^{2}\right)$}

Koefisien Determinasi $\left(\mathrm{R}^{2}\right)$ bertujuan untuk mengukur seberapa jauh kemampuan model dalam menerangkan variasi variabel dependen. Nilai koefisien determinasi adalah antara nol dan satu. Nilai $\mathrm{R}^{2}$ yang kecil berarti kemampuan variabel-variabel independen dalam menjelaskan variasi variabel dependen amat terbatas. Nilai yang mendekati satu berarti variabel-variabel independen memberikan hampir semua informasi yang dibutuhkan untuk memprediksi variasi variabel dependen.

\subsection{Definisi dan Pengukuran Variabel}

\subsubsection{Variabel dependen (Y)}

Variabel dependen (variabel terikat) merupakan variabel yang dipengaruhi atau yang menjadi akibat, karena adanya variabel bebas. Variabel terikat (dependent variabel) dalam penelitian ini yaitu Harga Saham. Harga saham yang merupakan harga penutupan (closing price) pada periode pengamatan.

\subsubsection{Variabel independen $(\mathrm{X})$}

Variabel bebas yang mempengaruhi atau yang menjadi sebab perubahannya atau timbulnya variabel dependen. Variabel bebas (independent variabel) yang digunakan dalam penelitian ini adalah Arus Kas Operasi dan Return On Asset (ROA). 


\section{HASIL ANALISIS DAN PEMBAHASAN \\ 4.1 Analisis Data \\ 4.1.1 Uji Asumsi Klasik \\ 1. Uji Normalitas}

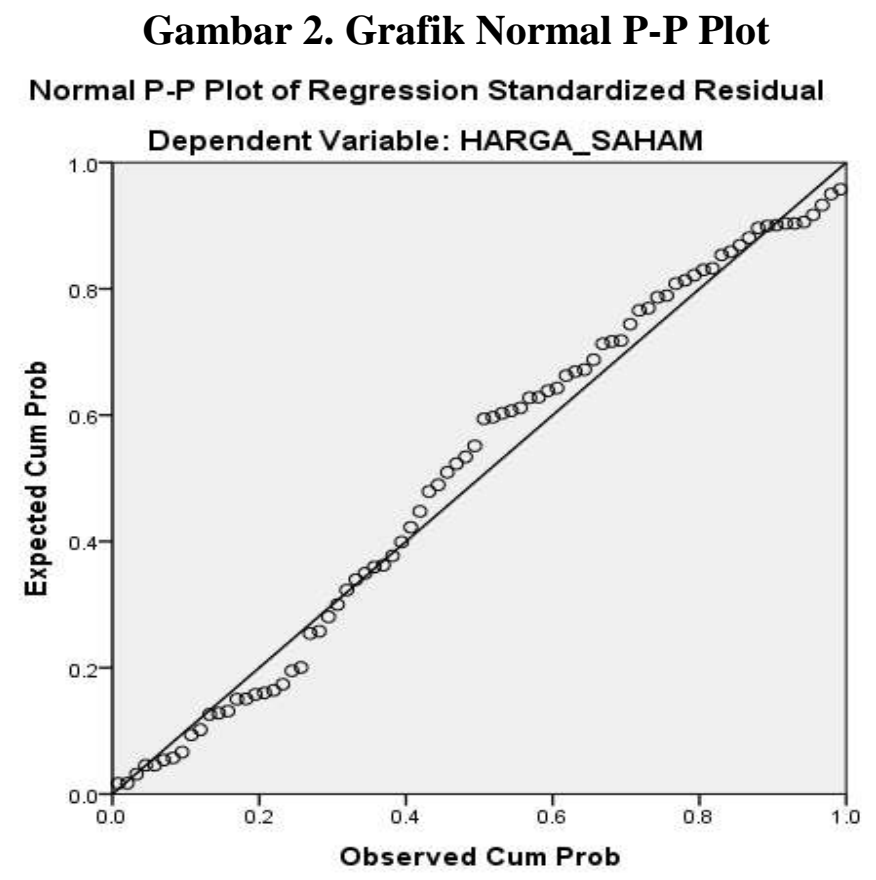

Sumber: Data Penelitian yang telah diolah, 2017

Gambar 2, terlihat bahwa sebaran data menyebar di sekitar garis dan mengikuti arahgaris. Dapat disimpulkan bahwa penelitian ini memenuhi uji normalitas.

2. Uji Multikolonieritas

Tabel 1.

Hasil Uji Multikolinearitas

\begin{tabular}{|c|c|c|c|c|c|c|c|c|}
\hline & \multirow[t]{2}{*}{ Model } & \multicolumn{2}{|c|}{$\begin{array}{l}\text { Unstandardized } \\
\text { Coefficients }\end{array}$} & \multirow{2}{*}{$\begin{array}{c}\begin{array}{c}\text { Standardized } \\
\text { Coefficients }\end{array} \\
\text { Beta }\end{array}$} & \multirow[t]{2}{*}{$\mathrm{T}$} & \multirow[t]{2}{*}{ Sig. } & \multicolumn{2}{|c|}{ Collinearity Statistics } \\
\hline & & B & $\begin{array}{l}\text { Std. } \\
\text { Error }\end{array}$ & & & & Tolerance & VIF \\
\hline \multirow[t]{3}{*}{1} & (Constant) & 2.040 & .653 & & 3.125 & .003 & & \\
\hline & $\mathrm{AKO}$ & .094 & .067 & .142 & 1.389 & .169 & .888 & 1.126 \\
\hline & ROA & .797 & .173 & .471 & 4.607 & .000 & .888 & 1.126 \\
\hline
\end{tabular}

a. Dependent Variable: HARGA_SAHAM

Sumber: Data Penelitian yang telah diolah, 2017

Dari hasil pengujian nilai tolerance pada tabel 1 di atas, nilai VIF yang dimiliki oleh variable arus kas operasi dan return on asset (ROA) adalah sama yaitu sebesar 1.126. 


\section{Uji Autokorelasi}

Tabel 2. Hasil Uji Autokorelasi

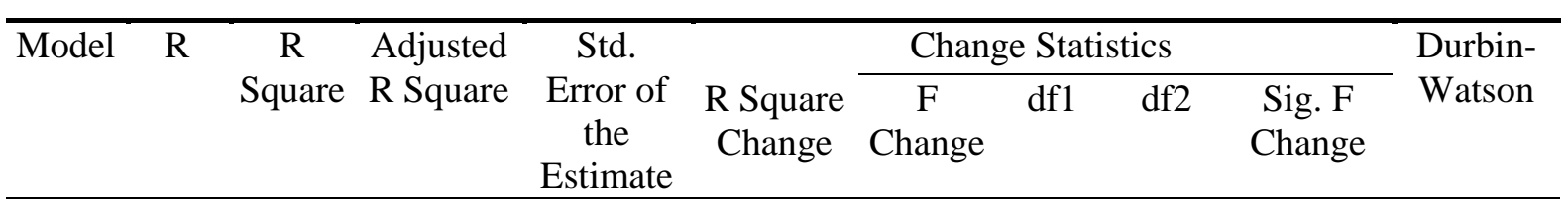

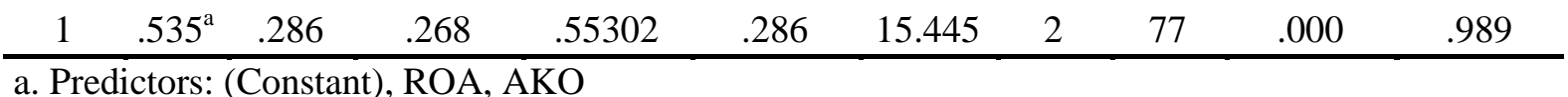

b. Dependent Variable: HARGA_SAHAM

Sumber: Data Penelitian yang telah diolah, 2017

Autokorelasi adalah korelasi antara sesama urutan pengamatan dari waktu ke waktu. Autokorelasi diuji dengan menggunakan Durbin-Warson (DW). Secara umum dengan diambil patokan dari :

1. Angka D-W dibawah -2 berarti ada autokorelasi positif.

2. Angka D-W diantara -2 sampai +2 berarti tidak ada autokorelasi.

3. Angka D-W diatas 2 Autokorelasi.

Dari table 2 diatas dapat dilihat bahwa Durbin-Watson (DW) yang didapatkan sebesar 0,989 maka disimpulkan bahwa tidak ada autokorelasi. Sehingga kesimpulannya adalah Uji Autokorelasi terpenuhi.

\section{Uji Heteroskedastisitas}

\section{Gambar 3. Hasil Uji Heteroskedastisitas}

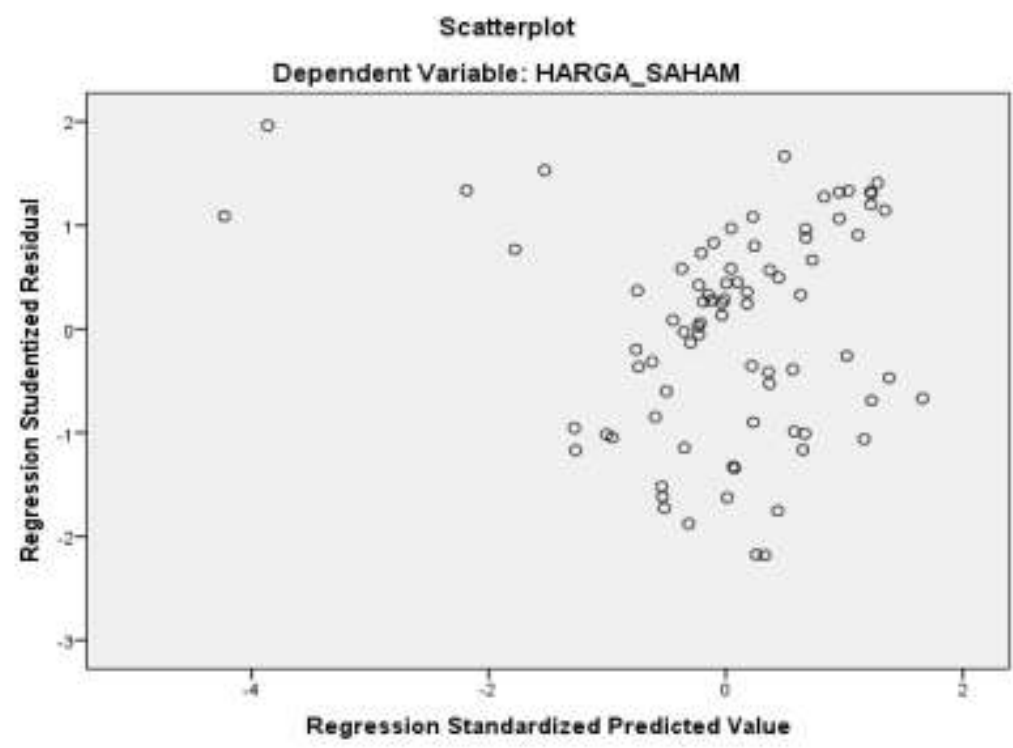

Sumber: Data Penelitian yang telah diolah, 2017

Gambar 3, Menunjukkan bahwa titik-titik tidak membentuk pola yang jelas serta titik-titik menyebar di atas dan di bawah angka 0 pada sumbu Y. Sehingga dapat dikatakan tidak ada gejala heteroskedastisitas. Maka uji heteroskedastisitas dalam penelitian ini terpenuhi. 


\subsubsection{Analisis Regresi Berganda}

Tabel 3.

Hasil Analisis Regresi

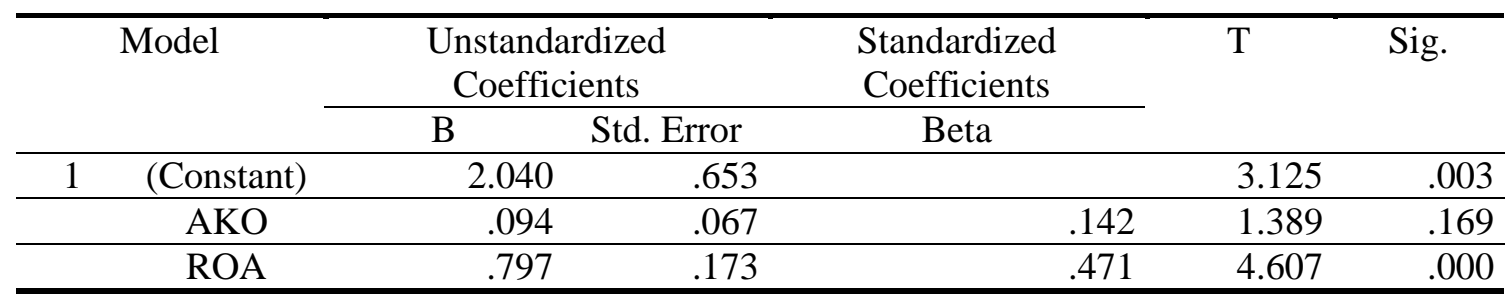

a. Dependent Variable: HARGA_SAHAM

Sumber: Data Penelitian yang telah diolah, 2017

Berdasarkan Tabel 3, maka dapat dilihat nilai konstan sebesar 2.040 dengan nilai signifikan 0,003 . Berdasarkan table diatas model regerensi yang di peroleh adalah sebagai berikut :

$$
Y=2,040+0,094 X_{1}+0,797 X_{2}
$$

Arti angka-angka tersebut sebagai berikut:

- $\quad$ Konstanta sebesar 2,040; artinya jika X1, X2, nilainya adalah 0, maka besarnya Y nilainya sebesar 2,040.

Koefisien regresi variabel $\mathrm{X}_{1}$ sebesar 0,094; artinya setiap peningkatan $\mathrm{X} 1$ sebesar 1 satuan, maka akan meningkatkan Y sebesar 0,094 satuan, dengan asumsi variabel independen lain nilainya tetap.

- $\quad$ Koefisien regresi variabel $\mathrm{X}_{2}$ sebesar 0,797; artinya setiap peningkatan $\mathrm{X} 2$ sebesar 1 satuan, maka akan meningkatkan Y sebesar 0,797 satuan, dengan asumsi variabel independen lain nilainya tetap.

Dalam penelitian ini, yang hanya di uji dalam aplikasi SPSS 20, dalam laporan keuangan yang menyangkut penelitian ini yaitu Arus Kas Operasi dan Return On Asset (ROA) dan Harga Saham hanya angka yang positif saja yang digunakan kalau angka negative tidak digunakan.

\subsubsection{Uji Hipotesis}

1. Analisis Koefisien Determinasi $\left(\mathbf{R}^{2}\right)$

Tabel 4. Hasil Uji Koefisien Determinasi

\begin{tabular}{|c|c|c|c|c|c|c|c|c|c|c|}
\hline \multirow[t]{2}{*}{ Model } & \multirow[t]{2}{*}{$\mathrm{R}$} & \multirow{2}{*}{$\begin{array}{c}\mathrm{R} \\
\text { Square }\end{array}$} & \multirow{2}{*}{$\begin{array}{l}\text { Adjusted } \\
\text { R Square }\end{array}$} & \multirow{2}{*}{$\begin{array}{l}\text { Std. } \\
\text { Error of } \\
\text { the } \\
\text { Estimate }\end{array}$} & \multicolumn{5}{|c|}{ Change Statistics } & \multirow{2}{*}{$\begin{array}{l}\text { Durbin- } \\
\text { Watson }\end{array}$} \\
\hline & & & & & $\begin{array}{c}\mathrm{R} \\
\text { Square } \\
\text { Change }\end{array}$ & $\begin{array}{c}\mathrm{F} \\
\text { Change }\end{array}$ & df1 & df 2 & $\begin{array}{l}\text { Sig. F } \\
\text { Change }\end{array}$ & \\
\hline 1 & $.535^{\mathrm{a}}$ & .286 & .268 & .55302 & .286 & 15.445 & 2 & 77 & 000 & .98 \\
\hline
\end{tabular}

a. Predictors: (Constant), ROA, AKO

b. Dependent Variable: HARGA_SAHAM

Sumber: Data Penelitian yang telah diolah, 2017

Dari Tabel 4, dapat dijelaskan bahwa model regresi tersebut memiliki koefesien determinasi $\left(\mathrm{R}^{2}\right)$ sebesar 0,286 atau 28,6\%. Hal ini menunjukan bahwa model regresi yang didapat mampu menjelaskan pengaruh Arus Kas Operasi dan Return On Asset (ROA) terhadap Harga saham $28,6 \%$. Sedangkan sisanya 71,4\% dijelaskan oleh faktor lain selain faktor yang diajukan dalam penelitian ini. 


\section{Uji F}

Tabel 5. Hasil Uji F

\begin{tabular}{|c|c|c|c|c|c|c|}
\hline & Model & Sum of Squares & $\mathrm{df}$ & Mean Square & $\mathrm{F}$ & Sig. \\
\hline \multirow{3}{*}{1} & Regression & 9.447 & 2 & 4.724 & 15.445 & $.000^{\mathrm{b}}$ \\
\hline & Residual & 23.549 & 77 & .306 & & \\
\hline & Total & 32.997 & 79 & & & \\
\hline
\end{tabular}

a. Dependent Variable: HARGA_SAHAM

b. Predictors: (Constant), ROA, AKO

Sumber: Data Penelitian yang telah diolah, 2017

Pada tabel 5, Hasil uji $\mathrm{F}$ menyatakan $\mathrm{F}_{\text {hitung }}=15,445$ dan $\mathrm{F}_{\text {tabel }}=3,07$ dengan hasil signifikan 0,000. Jadi dengan demikian dapat dilihat $F_{\text {hitung }}>F_{\text {tabel }}$ artinya variabel Arus Kas Operasi $\left(\mathrm{X}_{1}\right)$ dan Return On Asset $\left(\mathrm{X}_{2}\right)$, secara bersama-sama mempengaruhi variabel Harga Saham (Y). Nilai $F$ table dapat dilihat pada table F statistic pada df $1=$ jumlah variabel -1 atau $3-1=2$ dan df $2=\mathrm{n}-\mathrm{k}-1$ atau $120-3=117$ ( $\mathrm{k}$ adalah banyaknya variable bebas dan terikat atau independen dan dependen).

3. Uji t

Tabel 6. Hasil Uji t

\begin{tabular}{|c|c|c|c|c|c|c|c|c|c|c|c|}
\hline & \multirow[t]{2}{*}{ Model } & \multicolumn{2}{|c|}{$\begin{array}{l}\text { Unstandardized } \\
\text { Coefficients }\end{array}$} & \multirow{2}{*}{$\begin{array}{c}\text { Standardized } \\
\text { Coefficients } \\
\text { Beta }\end{array}$} & \multirow[t]{2}{*}{$\mathrm{T}$} & \multirow[t]{2}{*}{ Sig. } & \multicolumn{3}{|c|}{ Correlations } & \multicolumn{2}{|c|}{$\begin{array}{l}\text { Collinearity } \\
\text { Statistics }\end{array}$} \\
\hline & & B & $\begin{array}{l}\text { Std. } \\
\text { Error }\end{array}$ & & & & $\begin{array}{l}\text { Zero- } \\
\text { order }\end{array}$ & Partial & Part & Tolerance & VIF \\
\hline & (Constant) & 2.040 & .653 & & 3.125 & .003 & & & & & \\
\hline \multirow[t]{2}{*}{1} & AKO & .094 & .067 & .142 & 1.389 & .169 & .299 & .156 & .134 & .888 & 1.126 \\
\hline & ROA & .797 & .173 & . 471 & 4.607 & .000 & .518 & .465 & .444 & .888 & 1.126 \\
\hline
\end{tabular}

a. Dependent Variable: HARGA_SAHAM

Sumber: Data Penelitian yang telah diolah, 2017

Dari Tabel 6 di atas Pengaruh dari masing-masing variabel Arus Kas Operasi dan Return On Asset (ROA) terhadap Harga Saham dapat dilihat dari arah tanda dan tingkat signifikansi sebagai berikut :

\section{Pengaruh Arus Kas Operasi Terhadap Harga Saham}

Berdasarkan tabel 4.10 dapat diketahui bahwa Arus Kas Operasi menghasilkan nilai $\mathrm{t}_{\text {hitung }}$ sebesar 1.389 sedangkan $\mathrm{t}_{\text {tabel }}$ sebesar 1.98045 yang berarti $t_{\text {hitung }}<\mathrm{t}_{\text {tabel }}$ dan variabel ini mempunyai tingkat signifikansi sebesar 0.169 yang apabila dibandingkan dengan derajat kesalahan yang telah ditentukan yaitu sebesar 5\% atau 0.05 maka nilai signifikansi variabel Arus Kas Operasi (AKO) lebih besar dari derajat kesalahan maka variabel Arus Kas Operasi (AKO) tidak mempunyai pengaruh yang signifikan terhadap Harga Saham.

\section{Pengaruh Return On Asset (ROA) Terhadap Harga Saham}

Berdasarkan tabel 4.10 dapat diketahui bahwa Return On Asset (ROA) menghasilkan nilai $t_{\text {hitung }}$ sebesar 4.607 sedangkan $t_{\text {tabel }}$ sebesar 1.98045 yang berarti $t_{\text {hitung }}>t_{\text {tabel }}$ dan variabel ini mempunyai tingkat signifikansi sebesar 0.000 yang apabila dibandingkan dengan derajat kesalahan yang telah ditentukan yaitu sebesar 5\% atau 0.05 maka nilai signifikansi Return On Asset (ROA) lebih kecil dari derajat kesalahan maka variabel Return On Asset (ROA) berpengaruh signifikan terhadap Harga Saham. 


\subsection{Pembahasan}

Dalam pengujian yang diteliti dalam penelitian ini hanya diambil yang hasil Arus Kas Operasi dan Return On Asset (ROA) yang positif saja tidak mengambil angka yang negative. Data sampel keseluruhan Arus Kas Operasi yang angka positifnya ada 82 data sampel keseluruhan dan tidak dipakai karena angkanya negative ada 38 data sampel, data keseluruhan Return On Asset (ROA) yang angka positifnya yang digunakan dalam penelitian ini 110 data sampel keseluruhan dan yang tidak dipakai ada 10 data sampel karena angkanya negative, data sampel keseluruhan Harga Saham Dipakai semua karena tidak ada angka yang negative.

\subsubsection{Pengaruh Arus Kas Operasi terhadap harga saham}

Dari hasil uji statistik (uji t) menunjukkan bahwa arus kas operasi tidak berpengaruh secara signifikan terhadap harga saham pada perusahaan perbankan di Bursa Efek Indonesia. Dapat dilihat dari tabel 4.10 dimana koefisien untuk variabel ini adalah 0,169, dengan nilai signifikan dibawah 0,05 (5\%). Artinya dapat disimpulkan bahwa Arus Kas Operasi tidak berpengaruh signifikan terhadap harga saham. Hasil penelitian ini tidak memberikan bukti empiris bahwa semakin tinggi Arus Kas Operasi akan meningkatkan nilai perusahaan, dengan kata lain hasil penelitian ini bertolak belakang dengan teori yang ada. Arus Kas Operasi yang tinggi mencerminkan hasil atau pendapatan yang akan diterima oleh pemegang saham untuk setiap lembar saham yang dimilikinya. Investor memerlukan pertimbangan yang digunakan sebelum investor memutuskan untuk berinvestasi. Arus kas operasi perusahaan yang besar membuat investor tertarik untuk menanamkan investasinya pada perusahaan tersebut. Permintaan akan saham yang meningkat mengakibatnkan peningkatan harga sahamnya. Jadi dapat disimpulkan dengan bila arus kas operasi tinggi akan meningkatkan harga saham. Dalam hasil penelitian ini sekaligus didukung oleh hasil penelitian yang dilakukan oleh Dian (2008) dan Meythi (2006), menyatakan bahwa variabel Arus Kas Operasi tidak berpengaruh secara signifikan terhadap harga saham. Akan tetapi, hal ini bertentangan dengan penelitian Wahyudi (2016), Menyatakan bahwa Arus Kas Operasi berpengaruh signifikan terhadap Harga Saham.

\subsubsection{Return On Asset (ROA) terhadap harga saham}

Dari hasil uji statistik (uji t) menunjukkan bahwa ROA berpengaruh signifikan terhadap harga saham pada perusahaan perbankan di Bursa Efek Indonesia. Dapat dilihat dari tabel 4.10 dimana koefisien untuk variabel ini adalah 0.000, dengan nilai signifikan dibawah $0,05(5 \%)$. Artinya dapat disimpulkan bahwa ROA berpengaruh signifikan terhadap harga saham, sehingga hipotesis ini terbukti. Jika laba yang dihasilkan oleh perusahaan meningkat, maka hasil yang didapat oleh perusahaan yaitu laba yang tinggi, sehingga mengundang para investor untuk melakukan jual-beli saham, karena melihat akan hasil dari laba yang baik dari perusahaan. Dalam hasil penelitian ini sekaligus didukung oleh hasil penelitian yang dilakukan oleh Rahmi, et al (2013) dan Yanti, et al (2013) menyatakan bahwa variabel ROA signifikan terhadap harga saham.

\section{KESIMPULAN DAN SARAN}

\subsection{Kesimpulan}

Berdasarkan kesimpulan dan pembahasan, hasil yang diperoleh menunjukkan:

1. Hasil pengujian menunjukkan bahwa Arus Kas Operasi tidak berpengaruh signifikan terhadap harga saham. Dapat dilihat dari table 4.10, dari uji statistik (uji t) dimana koefisien untuk variable ini adalah 0,169, dengan nilai signifikan dibawah 0,05 (5\%).

2. Hasil pengujian menunjukkan bahwa Return On Asset (ROA) berpengaruh signifikan terhadap harga saham. Dapat dilihat dari table 4.10, dari uji statistik (uji t) dimana koefisien untuk variable ini adalah 0,000, dengan nilai signifikan dibawah 0,05 (5\%). 


\subsection{Saran}

Berdasarkan hasil penelitian dan pembahasan yang telah dilakukan, selanjutnya saransaran yang dapat disampaikan melalui hasil penelitian agar mendapatkan hasil yang lebih baik adalah sebagi berikut:

1. Bagi perusahaan dapat lebih meperhatikan dan meningkatkan kinerja keuangan di perusahaan agar dapat menarik dan meningkatkan kepercayaan investor untu berinvestasidi perusahaan.

2. Bagi investor harus memperhatikan macam-macam faktor yang dapat mempengaruhi harga saham untuk berinvestasi di perusahaan yang diinginkan. Dalam hal ini investor dapat melihat faktor-faktor yang terkait dalam perusahaan seperti Arus Kas Operasi dan ROA (Return On Asset).

3. Kepada Dosen di Fakultas Ekonomi dan Bisnis Universitas Sam Ratulangi untuk melih memperhasikan kembali peran penting Mahasiswa.

4. Kepada Mahasiswa-mahasiswa jangan lupa akan peran penting kalian sebagai generasi yang akan menggantikan geresi yang telah kusam oleh zaman.

5. Penelitian selanjutnya diharapkan dapat menggunakan objek penelitian yang lebih luas, tidak hanya perusahaan perbankan atau pada industri lannya, dapat menggunakan periode pengamatan yang lebih panjang. Selain itu, dapat menggunakan faktor-foktor external lainnya seperti tingkat suku bunga, inflasi, dan kurs valuta asing.

\section{DAFTAR PUSTAKA}

Anjani, Juwita Rini Dwi. 2016. Pengaruh Informasi Arus Kas, Laba Kotor, Ukuran Perusahaan,Return On Asset (ROA) Dan Debt Equty Ratio (DER) Terhadap Return Saham (Studi Empiris ada SektorAneka Industri Yang Terdaftar DI Bursa Efek Indonesia Tahun 2012-2014). Universitas MuhammadiyahSurakarta.

Dian. 2008. Pengaruh Informasi Laba Akuntansi, Total Arus Kas, dan Komponen Arus Kas Terhadap Harga Saham Pada Perusahaan LQ 45. Skripsi. Sekolah Tinggi Ilmu Ekonomi, MUSI. Palembang.

Ghozali, Imam. 2011. “Aplikasi Analisis Multivariate dengan program IBM SPSS 19”, Edisi

5 Cetakan V, Badan Penerbit Universitas Diponegoro, Semarang.

Hery. 2015. Analisis laporan keuangan pendekatan rasio keuangan. Center for Academic Publishing Service (CAPS). Yogyakarta.

Hutami, Resciyana Putri. 2012. Pengaruh Dividen Per Share (DPS) Return On Equity (ROE), Dan Net Profit Margin (NPM) Terhadap Harga saham Perusahaan Industri Manufaktur Yang Tercatat Di Bursa Efek Indonesia (BEI) Periode 2006-2010. Jurnal Nominal /Volume 1Nomor 1 / Tahun 2012. http://journal.uny.ac.id/index.php/nominal/\%20article/download/1001/804. Diakses Desember 2016. Halaman 104-123.

Husnan, Suad. 2009. Dasar-dasar Teori Portofolio \& Analisis Sekuritas. Edisi Keempat. Yogyakarta: UPP STIM YKPN.

Ikatan Akuntansi Indonesia. 2012. Standart Akuntansi Keuangan, Salemba Empat, Jakarta. Kadarusman, Lailatus Sa'adah. 2014. Pengaruh Laba Akuntansi, Komponen Arus Kas, Ukuran Perusahaan Terhadap Harga Saham Pada Perusahaan Kelompok LQ 45 Yang Listing di Bursa Efek Indonesia. STIE Malangkucecwara Malang. Volume 3, Nomor 2, Agustus 2014.

Kasmir. 2012. Analisis Laporan Keuangan. Cetakan Keenam. PT Raja Grafindo, Jakarta. Kasmir. 2015. Analisis Laporan Keuangan. PT. Grafindo Persada. Jakarta. 
Kurniawan, Juliana. 2013. Prediksi Laba Bersih \& Arus Kas Operasi terhadap Dividen dan Usaha Sektor Manufaktur di BEI. Jurnal Ilmiah Mahasiswa Universitas Surabaya, Vol.2 No 1.

Meythi. 2006. Pengaruh Arus Kas Operasi Terhadap Harga Saham Dengan Persistensi Laba Sebagai Variabel Intervening. Simposium Nasional Akuntansi 9 (Padang), K-AKPM 01, hal.1-21.

Rahmi, A., Arfan, M., \& Jalaluddin. 2013. Pengaruh Faktor- Faktor Fundamental Dan Risiko Sistematik terhadap Harga Saham (Studi pada Perusahaan Manufaktur yang Terdaftar di Bursa Efek Indonesia Periode 2007- 2009). Jurnal Akuntansi Pascasarjana Universitas Syiah Kuala. Vol. 2, No. 2, pp. 1-15.

Raja Adri Satriawan Surya, 2012. Akuntansi Keuangan Versi IFRS+. Graha Ilmu: Pekanbaru. Reeve, James M.; Carl S. Warren; Jonathan E. Duchac; Ersa Tri Wahyuni; Gatot Soepriyanto; Amir Abadi Jusuf dan Chaerul D. Djakman. 2013. Pengantar Akuntansi Adaptasi Indonesia Buku 2.Indeks. Jakarta

Sulia. 2012 . Pengaruh Laba Akuntansi, Arus Kas, Dan Debt To Equity Terhadap Harga Saham Perusahaan LQ-45 Yang terdaftar di Bursa Efek Indonesia. Jurnal Wira Ekonomi Mikroskil. Volume 2, Nomor 02, Oktober 2012.

Sonia, Siska Citra. 2013. Pengaruh Arus Kas Operasi Terhadap Harga Saham Pada Subsektor Pertambangan Logam Dan Mineral Di Bursa Efek Indonesia. Universitas Pendidikan Indonesia.

Wahyudi, Wasmin Muhamad. 2016. Pengaruh Profitabilitas dan Arus Kas Operasi Terhadap Harga Saham Pada Perusahaan Otomotif Yang Terdaftar Di Bursa Efek Indonesia. Universitas Batam. Volume 9 N0.2, 2016.

Watung, Rosdiana Widiawati. 2016. Pengaruh Return On Asset (ROA), Net Profit Margin (NPM), Dan Earning Per Share (EPS) Terhadap Harga Saham Pada Perusahaan Perbankan Di Bursa Efek Indonesia 2011-2015. Jurnal EMBA. Vol.4 No.2 Juni 2016, Hal. 518-529.

Wauran, Patrick C. \& Tumbuan, Willem J F Alfa. 2014. Bank dan Pasar Modal. Fakultas Ekonomi dan Bisnis. Universitas Sam Ratulangi. Manado.

Yanti, O.D. 2013. Pengaruh Faktor-Faktor Fundamental Terhadap Harga Saham LQ45 di Bursa Efek Indonesia (BEI). Jurnal Ekonomi. STIE MDP, pp. 1-10. 